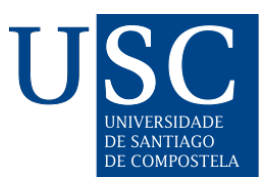

\title{
El régimen jurídico del patrimonio cultural subacuático
}

SARAH GONÇALVES RIBEIRO ${ }^{1}$

Fundação Escola do Ministério Público, España

ribeirogsarah@gmail.com

Essa resenha pretende analisar a obra do Professor Rubén Miranda Gonçalves: "El régimen jurídico del patrimonio cultural subacuático”, publicado pela editora Tirant lo Blanch. Esse estudo visa a proteção e a preservação do patrimônio cultural subaquático. Faz-se nele um estudo histórico e aprofundado de Direito Comparado para se verificar como essa questão é regulamentada à nível internacional. Segundo o autor, o Ordenamento Jurídico espanhol não prevê a sua proteção constitucional e isso desencadeou um processo autônomo regulador em algumas províncias do país. 0 estudo se fez baseado em fontes primárias demonstrando a criação da Convenção da UNESCO de 2001 e o desenvolvimento das legislações, bem como a sua aplicação em diferentes países.

Primeiramente, ressalta-se que a obra a ser analisada merece reconhecimento, pois faz um detalhamento histórico de Direito Comparado sobre um patrimônio cultural da humanidade. É imensurável o valor histórico que os naufrágios representam para a humanidade, destacando no modo de vida, trabalho, guerra etc. Dessa forma, a preservação do patrimônio subaquático simboliza, também, a conservação cultural das civilizações passadas da história.

Essa obra está estruturada em uma introdução, quatro capítulos e uma conclusão. 0 seu primeiro capítulo titulado: “Aproximación conceptual al patrimonio cultural subacuático”, Miranda Gonçalves trata do conceito doutrinário de património cultural e da sua diferenciação ao que se compreende por patrimônio cultural subaquático.

Como destacado pelo professor, na Espanha não há legislação específica para o patrimônio cultural subaquático, ela se faz indiretamente pelo artigo $1^{\mathrm{o}}$ da LPHE, que diz: "integram o patrimônio histórico cultural espanhol o imobiliário e objetos móveis de interesse artístico, histórico, paleontológico, arqueológico, etnográfico, científico e técnico. Também fazem parte desse mesmo patrimônio documental e bibliográfico os depósitos e zonas arqueológicas, assim como os sítios naturais, jardins e parques que tenham valor artístico histórico e antropológico".

O segundo capítulo denominado: "La Convención sobre la protección del patrimonio cultural subacuático de 2001", o autor faz uma breve introdução do capítulo para ilustrar o nascimento e a criação, bem como os princípios e objetivos da Convenção. Logo após passa a ilustrar as distinções de espaço marinho, a entrada em vigor da Convenção e finalizou detalhando as normas relativas as atividades do patrimônio cultural subaquático.

A Convenção da UNESCO, foi o resultado de inúmeros projetos que foram oficializados no ano de 2001. Ela definiu "patrimônio cultural subaquático" como o resquício da existência humana 
que tenha caráter cultural, histórico e arqueológico, que esteja submerso parcial ou totalmente, periódica ou continuamente, por pelo menos 100 anos. Além disso, ela regulamentou princípios para a sua preservação que versam sobre a sua preservação e proteção.

No terceiro capítulo foi feito um estudo comparativo, com base no Direito Comparado, da proteção cultural subaquática. A comparação foi feita com base no Sistema Jurídico Civil Law (Direito continental Europeu e Latino-americano), utilizando os exemplos da Itália, França, Portugal, Colômbia, Brasil e Argentina, com o Common Law, que se destacou os modelos do Reino Unido e dos Estados Unidos da América.

Como destacado pelo professor Miranda Gonçalves, apesar de não haver regulamentação específica para a proteção do patrimônio subaquático, essa regra não se aplica para alguns países. Ele destacou que diversos países de origem Civil Law, como Itália e França, possuem leis próprias de proteção, bem como alguns países de origem anglo-saxã, porém elas se distinguem nos níveis e especificidades das suas normas reguladoras.

Por fim, no quarto capítulo: "Régimen jurídico del patrimonio cultural subacuático en la legislación española", é feito um estudo da origem da regulamentação do patrimônio cultural subaquático na legislação espanhola anterior à Convenção de 2001, bem como o detalhamento do tema em texto constitucional e legislativo. Foi ressaltado por Miranda Gonçalves que apesar de haver meios legais indiretos de proteção ao patrimônio subaquático na Espanha, não há, no país, atualmente, qualquer lei que trate do assunto de forma direta e específica.

Concluo essa resenha fazendo uma homenagem ao autor pelo seu estudo, que demonstrou clareza e conhecimento sobre o tema ilustrado. A obra ilustra uma tese de conteúdo fundamental para a proteção do patrimônio cultural e preservação da história da civilização. Sabe-se que, atualmente, a tecnologia possibilitou avanços significativos para mergulhadores, o que ampliou extravios do patrimônio cultural subaquático. A importância desse estudo não está na sua matéria, mas na sua origem, ou seja, a riqueza subaquática não é econômica, mas cultural e esta merece proteção e preservação.

\section{Información Adicional:}

Título: El régimen jurídico del patrimonio cultural subacuático

Autor: Rubén Miranda Gonçalves

Editorial: Tirant lo Blanch Brasil

Año de edición: 2020

Páginas: 302

ISBN Papel: 9786587684000

ISBN Ebook: 9786587684048

NOTAS

1 Pós graduanda em Direito pela Fundação Escola do Ministério Público e em Direito Médico pelo Centro Universitário Curitiba. Graduada em Direito pela Universidade Positivo. Bacharelanda em Filosofia pela Universidade Claretiano. Email: ribeirogsarah@gmail.com 